\title{
Quality Analysis of the Written Russian Language of Students of Latvia
}

\begin{abstract}
A decrease in the quality of the written language of students is one of the most topical and therefore one of the most heatedly discussed problems among teachers and students' parents; it is one of the problems discussed in linguadidactics. In the following article issues regarding young students' linguistic behaviour in their native (Russian) language have been analysed. The material presented in the article is based on the results of a scientific research conducted in schools throughout Latvia in 2008.

The aim of the study is to identify to what extent the development of the linguistic personality of young students in their native (Russian) language is successful. To this end, primary school teachers analysed the situation regarding the development of the written linguistic behaviour of students of Grade 4. The issues were identified, typical linguistic mistakes were noted and characterised, and reasons for making them were found out.

During the research, 55 primary school teachers filled out a questionnaire; 735 papers written by students of Grade 4 from various schools in Latvia were analysed; a comparative analysis of teachers' opinions was carried out to uncover problem areas of the students' linguistic behaviour.

The results of the conducted study allows drawing the following conclusions:

- In many ways, primary school teachers see the situation regarding linguistic literacy differently in comparison to what it actually is like.

- The quality of the written Russian language of primary school students directly depends on what type of bilingual educational model is implemented in the class or school.

- Most often the reason for a language mistake found in the written language of a student is complex.

- The analysis of the students' written language shows that the development of their Russian linguistic personality proceeds with insufficient success.

Key words: native (Russian) language in the diaspora, linguistic behaviour of young students, bilingualism, spelling and punctuation mistakes, textual skills

\section{Introduction}

In 2008, on the commission of the Ministry of Education and Science of the Republic of Latvia a study of the written linguistic behaviour of Russian-speaking students of Grade 4 was conducted (Gavriḷina, Līcīte, Frolova, 2008). 735 students
\end{abstract}


of Grade 4 and 55 teachers from various schools in Latvia participated in the study. The schools are bilingual and sometimes use Russian as the language of instruction.

The analysis of the teachers' responses to the questions posed in the questionnaire as well as the analysis of the papers written by the students allows to:

- Identify the way teachers view the situation concerning the students' literacy in the area of the native (Russian) language which is formed by the end of the initial stage of mastering the native language;

- Identify peculiarities of the linguistic (written) behaviour of students of Grade 4 in their native language (syntax);

- Identify the weak points and typical spelling and punctuation mistakes in the written language made by students of Grade 4, as well as identify causes of rather low level of their language literacy.

\section{Aim of the study}

In the course of the study, the following objectives were set:

1) To see how primary school teachers assess the quality of young students' written language and to compare their understanding with the real situation;

2) To assess the quality of fourth-graders' written linguistic behaviour, to notify their linguistic achievement and difficulties, and to identify reasons for linguistic failures;

3) To produce didactic recommendations for primary school teachers that would encourage a more rapid process for the development of young students' linguistic personality in their native (Russian) language.

\section{Materials and methods}

During the research 55 primary school teachers filled out a questionnaire and 735 papers written by students of Grade 4 of various schools in Latvia were analysed; a comparative analysis of the teachers' opinions and the actually existing problems found in the students' linguistic behaviour was done.

\section{Results}

Since the framework of the article does not allow a full review of the entire list of the linguistic mistakes and imperfections found in texts written by the students, we shall discuss in greater detail only those that are of a frequent character and considerably reduce the quality of texts created by the students.

\section{Spelling literacy}

\section{Analysis of the teachers' viewpoints}

Most primary school teachers (73\%) who took part in the polling consider that the level of spelling literacy of students should be assessed as "close to average" or "low". 
Based on great experience and observation skills, the teachers pointed out the following spelling mistakes and labelled them as typical in the students' written language:

- checkable and non-checkable unstressed vowels in word roots;

- the unstressed vowels $e$ and $u$ in the case endings of nouns and personal endings of verbs;

- the vowels $o(\ddot{e})$ and $e$ after sibilants and $u$.

Besides, almost every teacher pointed out that spelling mistakes connected with the choice of a checkable vowel in the word root were hard to eliminate. We can only add that the orthogram "Spelling of a checkable unstressed vowel in the word root" is traditionally considered to be one of the most difficult orthograms of the Russian language since in this case spelling requires considerable intellectual effort and rich linguistic experience.

An analysis of the answers given by the teachers to the question "What orthograms, in your opinion, should students have completely mastered by the end of Grade 4?" allows to draw a conclusion that the teachers place too high demands on students of Grade 4 as regards the development of spelling literacy. Therefore it is hard to agree to the requirement that by the end of Grade 4 students should correctly spell words that include such orthograms as "Checkable unstressed vowel in the word root", "The Russian letter" $b$ " in words", "Writing of нe with different parts of speech". As is well known, the given spelling patterns are of a complex character (under one name they combine several norms that are not completely known to young students), and they require not only the skill to identify an orthogram in a word but also select a method for proving the correct spelling and develop reasoning skills when a spelling problem must be solved. Fourth-graders only begin to form such skills.

As seen by teachers, the main reasons for the low level of students' literacy are as follows:

- Insufficient number of lessons allotted in the teaching curricula for mastering the native language in the primary school (this was pointed out by $96 \%$ of the teachers);

- Insufficient significance attached to the written communication in the contemporary society ( $82 \%$ of teachers);

- Lack of need to read fiction for most of contemporary students (67\%).

The majority of the teachers (85\%) see a solution to the situation by increasing the number of the native language lessons in the primary school that would allow devoting more attention to the "improvement of children's spelling skills".

\section{Results of the analysis of students' papers}

While analysing the linguistic behaviour of students of Grade 4, the authors of the study identified typical and recurrent spelling mistakes in the students' written language and evaluated the following skills: 
- To solve spelling tasks in words in which the place of a particular orthogram has been marked;

- To choose the right spelling in sentences, argument the choice proving reasoning skills when it comes to solving spelling problems in words;

- To notice spelling mistakes in someone else's writing, correct them and substantiate the opinion;

- To comply with the spelling norms that have already been mastered in one's own language (text).

As a result of the analysis of the students' written papers the following typical spelling mistakes were registered:

- Checkable unstressed vowels in word roots;

- The unstressed vowels $e$ and $u$ in the case endings of nouns;

- The letters 3 and $c$ at the end of prefixes;

- The Russian letter " $\mathrm{b}$ " in words;

- Non-checkable unstressed vowels in word roots;

- The unstressed vowels $e$ and $u$ in the case endings of nouns;

- Separate writing of He with verbs;

- Capital letter in proper nouns;

- Double consonants in word roots.

Thus, the analysis of children's written works has shown that the students trained according to the $1 \mathrm{st}$ and 2 nd bilingual models, make considerably more mistakes in words containing the following orthograms: "The letters 3 and $c$ at the end of prefixes", "The Russian letter " b " in words", "Double consonants in word roots", "Separate writing of the prefix He with verbs" (in comparison with students who study following the 3rd and 4th bilingual models). Thus, when writing words with the orthogram "He with verbs", $46 \%$ of students who study following the 1st and 2 nd bilingual models and only $9 \%$ of students who follow the 3rd and 4th models make regular mistakes.

Approximately one third of the fourth-graders who participated in the study made mistakes in writing orthograms which, in our opinion, should be mastered by the given stage. $29.3 \%$ of all students make mistakes regularly in spelling words that contain the orthogram "Capital letter in proper names". It occurs when children write toponyms (most often they are place names of geographical objects located outside Latvia). Moreover, almost one third of the fourth-graders (26.8\%) write prepositions and pronouns together (this occurs less often with nouns). In most cases these mistakes are characteristic of children who study according to the $1 \mathrm{st}$ bilingual model.

The analysis of fourth-graders' written language shows, that students make more spelling mistakes in their own written texts, as well as in situations when it is necessary to find and correct mistakes in someone else's text. If the place of the orthogram is marked in the text, mistakes occur less often. For instance, when doing 
a complex checking task, students worked with the orthogram "The unstressed vowels $e$ and $u$ in the personal endings of verbs". Following the instruction to fill in the missing letters in the verb endings, only $16.6 \%$ of all students made mistakes. When students had to detect mistakes of the given orthogram in the text, $41.4 \%$ of them made mistakes. When writing their own texts, $42.5 \%$ of all fourth-graders made mistakes in words containing the above mentioned orthogram. Such a great difference in students' success while performing the given tasks allows us to arrive at the conclusion that by the end of Grade 4 many students have insufficiently developed skills to notice complicated spelling cases which, according to linguadidactics, belong to basic spelling skills (Разумовская, 1996). The majority of children are taught to follow a set of spelling operations; only for a few of them when they write a text of their own "correct spelling as part of the structure of spelling procedure has become a technical and automated operation" (Репкин, Репкина, 1997).

The results of the study also allow to conclude that the majority of the students who participated in the research have an underdeveloped skill of justifying the choice of one or another way of spelling a word, which is one of the most important spelling skills. Although $97 \%$ of the students solved spelling problems in the words offered correctly, yet $52 \%$ of them gave a wrong reason for the choice of the letters, and $8 \%$ of the children did not even attempt to give any reason at all.

\section{Comparative analysis of the teachers' opinions and the results of the written tasks performed by the students}

The comparative analysis of the teachers' opinions concerning the students' literacy and the results obtained in the course of the analysis of the students' written works shows that the teachers' opinions only partially correspond to the real situation.

However, one has to agree with the teachers that the level of spelling literacy of the fourth-graders who participated in the study cannot be considered satisfactory.

The teachers' viewpoint concerning what spelling errors made by the fourthgraders should be regarded typical and stable in many respects does not correspond to the actual situation. The teachers are right in considering that students have difficulty writing the checkable and non-checkable unstressed vowels in words. The teachers identify the level of difficulty for the students in respect of the orthograms in the following way (the top of the list mentions the most difficult orthograms):

- writing of checkable unstressed vowels in word roots;

- writing of non-checkable unstressed vowels in word roots;

- writing of the unstressed vowels $e$ and $u$ in the case endings of nouns;

- writing of the unstressed vowels $e$ and $u$ in the personal endings of verbs.

The analysis of the students' written works shows that the students rate the difficulty of the orthograms slightly differently. The most difficult orthogram, 
similarly to the teachers' opinion, appears to be "Checkable unstressed vowels in word roots". Then follows the orthogram. "The unstressed vowels $e$ and $u$ in the case endings of nouns". The orthogram "Non-checkable unstressed vowels in word roots" rates number five and the orthogram "The unstressed vowels $e$ and $u$ in the personal endings of verbs" - number six.

Teachers underestimate the difficulty caused to the fourth-graders by the orthogram "Doubling of consonants in word roots". Yet regular mistakes in following this orthogram are made by $49 \%$ of all students. The tendency of writing one consonant instead of two is clearly visible in the children's written works (for instance, тенис instead of теннис, Росия instead of Россия, etc.). The reason for this lies in interlinguistic interference: in Latvian there are relatively few words with double consonants in their roots. Consonant letter doubling in Russian words often corresponds to a single consonant letter in analogous words in Latvian.

Only $10 \%$ of the teachers indicated that the orthograms "Capital letter in personal names" and "Separate writing of He with verbs" cause a spelling difficulty. In reality, one third of the students (29.3\%) make mistakes following the first orthogram, and $38 \%$ of students prefer to write He together with verbs.

The same refers to the orthogram "The Russian letter " b " in words". Only $18 \%$ of all teachers consider this orthogram a "risk zone". However, the analysis of the students' writings shows that mistakes are made by $39 \%$ of the fourth-graders. It can be added that similar mistakes were discovered when children were dealing with various other orthographic tasks.

One can agree with the teachers that one of the basic reasons for students' low spelling literacy is the fact that they read too little. What indicates to it is the fact that children regularly make the following mistakes: they write prefixes together with nouns and pronouns (i.e. they write what they hear putting a phonetic word into writing). This mistake regularly occurs in essays by students who study according to the 1st bilingual model (90\%); as a result, text comprehension is substantially impaired.

None of the teachers who presented causes of the great number of spelling mistakes in the students' written language indicated that the fourth-graders were not aware of orthograms in words; when a spelling issue must be resolved they cannot reason effectively enough. The analysis of the students' writings shows that $60 \%$ of the students cannot find the right argument for choosing one or another way of spelling a word.

The reason of that, as pointed out by $42 \%$ of the teachers, is the influence of the orthographic norms of the Latvian language upon the quality of students' Russian language. It is evidenced in practice (this reason was pointed out by $73 \%$ of teachers working at schools in which the 1 st and the 2 nd bilingual models are implemented). 
Writing of the particle не together with verbs was found to be a characteristic mistake for $38 \%$ of the fourth-graders. It might be caused not so much by the inability to identify a particular word as a verb (this is an important feature of the above-mentioned orthogram), than by the influence of the contrasting norm in the Latvian language. The regularity and persistence of the above type of mistakes in students' writings can be explained by the interrelation of the spelling norms of the Russian and Latvian languages and their interference in students' minds. For instance, in Latvian ne is always written together with verbs, whereas the corresponding word in Russian - separately. The teachers of the Latvian language indicate that when Russian students write in Latvian, they often make a mistake of the same kind: they write ne separately from the verb (for instance, ne gribu, ne varu), i. e. they follow the spelling rule of Russian. In other words, the students' language experience (consciousness?) gives space for "hybrid" spelling rules of both languages that have contrasting interrelation.

A similar "hybridisation" can be considered one of the causes leading to an incorrect spelling of Russian prefixes ending in the letters 3 and c. The writing of bez-, uz- and similar prefixes in Latvian follows the morphological spelling principle; in Russian, however, the spelling is determined by the phonetic principle (The Latvian prefix bez-corresponds to the Russian allomorphs без- / бес-). This encourages students to choose the letter $3 ; 47 \%$ of the fourth-graders make a mistake (for instance, без्зллатный instead of бесплатный, разикинулся instead of раскинулся, еtc.).

It is noteworthy that students make even more mistakes when they write prefixes ending in 3 и $c$ than when try to cope with the orthogram "He with verbs". The situation described proves a conclusion reached by psycholinguists: interference in students' language emerges more often when the rules of the first and the second languages partly coincide (as in the case with the prefixes: бeз- / бec- = bez-), not when the rules are completely different (as in the case of spelling Hе before verbs).

Besides the enlisted spelling errors found in the students' essays, mistakes in Russian graphemes (graphical mistakes) were identified in the works of the students who study according to the 1 st and 2 nd bilingual models: writing the Latin grapheme $u$ instead of the Russian letter y (for instance, не покини instead of не покину, фитбол instead of футбол, etc.); writing the grapheme $e$ instead of the letter $\ni$ at the beginning of words (for instance, Естония instead of Эстония, $y$ emozo instead of $y$ этого, emu instead of эmu,etc.); writing ŭ according to the pronunciation of words (for instance, йолка instead of ёлка, пойеду instead of noeдy, etc.). Besides, in $61.5 \%$ of the students' texts one can find phrases characteristic of the Latvian language.

\section{Analysis of the students' linguistic behaviour when creating their own texts}


The analysis of the Russian speaking fourth-graders' essays allows to conclude that one of the peculiarities of their written communication is "linguistic pragmatism"; it is manifested in the volume of texts to be written and their syntactic structure, and in using (or, rather not using!) linguistic expressive means.

According to our study the overwhelming majority of the fourth-graders prefer writing short texts usually not exceeding 50-90 words (including function words). Children do not tend to expand on micro-themes: they are usually only enlisted. As a result, students' essays are more informative in their character; they contain hardly any element of artistic language. The analysis of the students' essays on the subject "My wonderful summer holidays!" shows the following:

- Only 9\% of the students had used 100-120 words in their texts (including function words); $68 \%$ had used $50-90$ words; $23 \%$ had used $30-50$ words;

- $83 \%$ of the fourth-graders had just enlisted events during their summer holidays (where they went, who they met, what they were occupied with), or what they plan to do during the next summer holidays.

This kind of a situation allows to assume that most fourth-graders try to form a written text according to the principles of the organisation of their real speech: they only aim to inform the addressee, to convey as much information in a short textual space as possible. This conclusion is also supported by the fact that in the written texts of nearly all students we found numerous mistakes called forth by word order characteristic of colloquial speech, for instance, Мои каникулы проводить буду хорошо. Летом в аквапарк поехать мама обещала. Пять минут от города к реке идти.

Another peculiarity characteristic of the students' written linguistic behaviour is the fact that children are extremely reluctant not only in using means of linguistic expression but also adjectives. It was established that there were almost no adjectives used in the essays of $87.5 \%$ of the students who study according to the 1 st bilingual model, and in the essays of $70 \%$ of the students who follow the 2 nd bilingual model. As to epithets, similes and other means of linguistic expression, they are avoided by $92 \%$ of all students who study according to the above bilingual models.

In our opinion, this alarming symptom has two causes. Firstly, it is the influence of the natural Russian linguistic environment in which the student resides. The linguistic behaviour of the Russian speaking population of Latvia is very pragmatic (its characteristics include receiving/ conveying information in a short period of time with the help of the most economic linguistic means); syntactically and stylistically it is elementary and often full of various kinds of linguistic mistakes; it is rich in slang. Secondly, it is the fact that under the circumstances of bilingual training, the student mastering the content of various school subjects with the help of the second language or in the second language cannot fully perceive the content and the aesthetics of the author's text because of insufficient knowledge of the 
language; as a result the student can only "grasp" the main information necessary for completing the given tasks. Fine details most often elude the students' field of vision or prove to be beyond their comprehension. The same occurs during the process of speaking or writing in the second (in our case - Latvian) language: the student conveys the most important message refraining from details. Afterwards this strategy of linguistic behaviour is transferred to the native language. The given situation most probably confirms the idea of scientists that when a child who speaks one language (in our case - Russian), plunges into a new language environment (in our case - in the educational environment where the Latvian language prevails), the first language becomes watered down or is even "erased". This is explained by the fact that "quick mastering of language skills [in the second language] is always accompanied by noticeable loss in the first language" (Александрова, 2006).

The analysis of syntactic constructions used by the children shows that the majority of the fourth-graders (89\%) in their own texts use constructions of the same type: simple extended sentences containing 5-9 words on average. As a result, the children's texts are syntactically monotonous.

The texts of $47 \%$ students contain simple sentences with homogeneous parts; in most cases they are the predicate and the object (in $89 \%$ of all texts). Complex sentences can be found in texts of only $11 \%$ of the students. This type has a subordinate clause as an explanatory part that is attached to the principal clause with the help of the conjunctions "that" or "so that".

$49 \%$ of the fourth-graders who study according to the 1st and 2nd bilingual models, frequently use the verb ecmb in their sentence structures (for instance, В Туриии есть большая башня. Там есть бассейн - один для взрослых, другой для детей. В этой стране есть вкусный белый шоколад). The occurrence of this verb in the children's Russian language can be explained by the influence of similar syntactic patterns of the Latvian language in which the use of the verb "ir" ("is") is justified by the language norm. It can be noticed that the tendency to use the verb "is" in Russian is very stable. A few years ago (in 2002 ) after analysing the written verbal behaviour of second-graders, the author of the present article made an observation that children frequently use this verb in their syntactic structures (Гаврилина, 2004). Texts written by many second-graders reminded translations from a foreign language into Russian. For instance, Около домика есть гараж. В гараже есть машина. На домике есть труба, есть крыша. В этом домике есть два окна. В домике есть дверь и ступеньки. Впереди домика есть ворота большие....

In our opinion, the results of the comparative analysis of the two situations referring to different periods of time prove that we are dealing with the influence of the Latvian language upon the development of the children's linguistic personality in the first (Russian) language. After all, the crossing of the norms of the native and second languages in young students' language consciousness is natural for the linguistic behaviour of a developing bilingual. However, (what is even more 
important!) the analysis proves that we have not managed to find effective didactic ways yet that would allow to mitigate the influence of the second language on children's linguistic behaviour in their native language.

Moreover, the written linguistic behaviour of $77 \%$ of the fourth-graders demonstrates a tendency to use the complex form of a verb in the future tense. In fact, essays of many children show that verbs in the above form can be seen almost in every sentence, or even as often as several times in one sentence. Let us take a look at an example:

Летом я буду ездить на футбол. Буду ехать в аквапарк. Я буду ездить к бабушке. Буду играть в компьютер. Гулять я буду. Маме я буду помогать. Буду лететь в Италию. Буду праздновать день рождения. И я буду веселым на летних каникулах.

If the frequency of the verb "is" can be considered a result of interlinguistic interference, the reason for the choice of the complex verb form in the future tense, most probably, is to be looked for elsewhere since all fourth-graders, irrespective of the bilingual model of their training, prefer using it. Besides, in Latvian there is no corresponding form.

The personal pronouns "I" and "we" appear inappropriately frequently in the written texts of $67 \%$ of the students (see the example given above). On the one hand, it corresponds to the empirical type of knowledge, characteristic of young students in their everyday life. On the other hand, however, it reduces the quality of texts considerably.

Another specific feature of the written linguistic behaviour of the fourth-graders is the use of Latin letters for spelling proper names. It refers to place names, names of organisations, vacation spots and so on. For instance, Моя бабушка живет в Asari (a location in Jūrmala); Мама купила абонемент в "Hotel Jurmala Spa" (a hotel name); Вчера мы всей семьей посещали ZOO centrs (a pet shop); По выходным я хожу в школу волшебников "LANDO"; Я отлично провел лето в лагере "Samurai 2008"; Я хотела бы увидеть башню "Big Ben", etc. The analysis of the names written in Latin letters in the children's texts shows that in the majority of cases students use them for names of various objects in Latvia, less often - for those related to other countries. In our opinion, it is indicative of the fact that features of the surrounding language environment show through the students' language; there are practically no names of stations, streets, establishments, shops, entertainment centres and similar objects written in Russian.

No doubt that the development of student's Russian language personality in Russia and in Latvia proceeds differently. In our case, under the circumstances of cultural and language variety, students find themselves in a more complex language situation since information about the world comes in fully or partly not just in one but at least in two languages. As a result, students simultaneously develop their primary (Russian) and secondary (Latvian) linguistic personalities. Nevertheless, the character of the mistakes and imperfections identified in the linguistic behaviour 
of the fourth-graders allows us to acknowledge the fact that the development of the Russian linguistic personality of our students does not proceed successfully enough. Linguistic personality, first of all, is known to be considered on the basis of the created texts. Mistakes and imperfections described in the article have mostly been identified in texts created by students themselves. In some cases their rate is so high that such texts become a challenge for the reader and the achievement of children's written communication becomes questionable.

\section{Conclusions}

The results of the study carried out allow revealing vital issues in language development of students of Grade 4, as well as to draw several conclusions.

1. In many ways, primary school teachers see the situation regarding the linguistic literacy differently from what it actually is. To a certain extent teachers are deluded by the situation regarding children's literacy what it was like 8-10 years ago. Such a state of affairs, in our opinion, does not allow planning the process of children's linguistic development in a didactic and competent way.

2. The quality of the written Russian language of the primary school students directly depends on what type of bilingual educational model is implemented in the class or school. The "spelling risk zones" for students who study according to the 1st, 2nd and 3rd, 4th bilingual models seem to be uncertain. Interlinguistic interference that we have observed in this case can be considered an ambiguous phenomenon. On the one hand, it can be viewed negatively since"it emerges on the surface" in the form of students' language mistakes (phonetic, spelling, grammar, semantic, etc. mistakes). On the other hand, it is an objective phenomenon that inevitably originates in cases of bilingual training, and, thus, requires searching for effective ways to be overcome. Therefore the main point is to establish what methods should be considered effective.

In our opinion, the described situation requires the teachers of the native (Russian) language and those of the second (Latvian) language to be aware of, firstly, the "risk zones" for the bilingual Russian-Latvian students, and secondly, to coordinate the didactic efforts in order to establish the sequence and methods for the development of the students' norms of two languages. Besides, it might be necessary to consider the opinions of those researchers who think that children's training of literacy (including spelling), based on a phonetic method, does not appear to be effective when young students are taught their native language in a context of bilingual formations (Ясюкова, 2007); under the given circumstances, the experience that has been gained by modern neurolinguists, such as the use of effective word memorisation strategies, might prove to be more effective (Павлова, 2000; Емельянова, Соболева, 2008).

3. It is clear that the development of modern students' literacy and stylistically rich written language places high claims on the schooling hours. One can agree 
with teachers who say that it would be reasonable to increase the number of the teaching hours allotted in the school curricula for the development of the native language. However, it is unlikely that this measure alone will guarantee reaching the desirable result. Experience shows that there is a complex of reasons at the bottom of one or another language mistake made by a student. Thus, if students write "безилатный" in their texts, the reasons for the given spelling mistake can be the influence of the language environment (a similar type of mistakes is often encountered in brochures, announcements, etc.), or the influence of the spelling norm of the Latvian language, or just as well insufficient reading experience and shortage of the training hours for mastering the given spelling rule. The success of the training and learning to correct mistakes in the given situation largely depends on the teacher's skill to organise students' activities in the classroom in such a way that the reasons of possible mistakes would be neutralised during the process.

\section{References}

1. Gavrilina, M., Līcīte, L., Frolova, I. (2008). Mazākumtautību (krievu) sākumskolas skolēnu valodā sastopamo ortogrāfijas un interpunkcijas problēmu raksturojums un to risinājuma iespējas [Orthography and Punctuation Problems in the Language of Minority (Russian) Primary School Students and Ways to Solve Them]. Rīga: IZM ISEC, 64 Ipp. http://isec.gov.lv/isec/petijumi/mazakumt_ortografija.pdf (in Latvian).

2. Pallier, C., Dehaene, S., Poline, J. B., LeBihan, D., Argenti, A. M., Dupoux, E. \& Mehler, J. (2003). Brain Imaging of Language Plasticity in Adopted Adults: can a Second Language Replace the First? Cerebral Cortex, Vol. 13(2), p. 155-161.

3. Александрова, Н.Ш. (2006). Родной язык, иностранный язык и языковые феномены, у которых нет названия [Native Language, Foreign Language and Nameless Linguistic Phenomena]. Issues of Linguistics, № 3, c. 88-100. (in Russian).

4. Гаврилина, М.А. (2009). Орфографическая грамотность младших школьников в родном языке в условиях билингвального образования [Young Students' Spelling Literacy of their Native Language in Bilingual Education]. Русский язык за рубежом [The Russian Language Abroad]. № 6. Москва, c. 51-56. (in Russian).

5. Емельянова, Е.Н., Соболева, А.Е. (2008). Пишу без ошибок. Русский язык с нейропсихологом [I do not make Mistakes in Writing. Russian with Neuropsychologist]. Санкт-Петербург: Питер (in Russian).

6. Павлова, М. А. (2000). Интенсивный курс повышения грамотности с помощью НЛП [Intensive Course for Improving Literacy]. Москва: Институт психотерапии (in Russian).

7. Разумовская, М. М. (1996). Методика обучения орфографии в школе [Methods of Teaching Orthography at School]. Москва: Просвещение (in Russian).

8. Репкин, В. В., Репкина, Н. В. (1997). Развивающее обучение: теория и рактика. Cmambu [Developmental Training:Theory and Practice. Articles]. Томск: Пеленг (in 
Russian).

9. Ясюкова, Л.А. (2007). Психолого-педагогические причины неграмотности современных школьников [Psychological - Pedagogical Reasons for Contemporary Students'llliteracy], № 1(2). Mockвa. (http://www.psy.su/prof_society/articles/2118) (in Russian).

10. Гаврилина, М. (2004). Русский язык в 4-5 классах: Книга для учителя [The Russian Language for Grades 4-5: Teacher's Book]. Rīga: Mācību grāmata (in Russian).

Prof. Dr. paed. Margarita Gavriḷina

University of Latvia, Faculty of Education,

Psychology and Art, Department of Pedagogy

Address: Jurmalas Gatve 74/76, Rīga, LV-1083, Latvia 